\title{
Survey of Citrus tristeza virus (CTV) on Citrus paradisi (Macfad.) cv. "Marsh" in South
} Africa

\author{
Read, D.A. ${ }^{2,4}$, Palacios, M.F. ${ }^{1}$, Figueroa, J. ${ }^{1}$, Stein, B. ${ }^{1}$, and G. Pietersen ${ }^{2,3 *}$ \\ ${ }^{1}$ Estación Experimental Agroindustrial Obispo Colombres (EEAOC), Tucumán, Argentina. ${ }^{2}$ Department of \\ Microbiology and Plant Pathology, University of Pretoria, South Africa. \\ ${ }^{3}$ Agricultural Research Council- Plant Protection Research Institute, South Africa. \\ ${ }^{4}$ Centre for Microbial Ecology and Genomics, University of Pretoria, Pretoria, South Africa \\ *Corresponding author: gerhard.pietersen@up.ac.za
}

\begin{abstract}
Citrus tristeza virus (CTV) is endemic throughout the citrus production areas of South Africa and mild-strain cross-protection is employed to combat the negative effects of severe-strain infections. The country is among the world's leading producers of grapefruit, however crossprotected trees often display severe stem grooving, regardless of the rootstock. Previously, cross-protection sources were evaluated empirically, through graft inoculations onto indicator hosts. Recent research has shown that cross-protection, possibly mediated by super-infection exclusion, is strain-specific. This, coupled with the varying affinities that cultivars display for different CTV strains, has shown the need to determine which CTV strains are associated with specific commercial cultivars. In this study, thirty-six Citrus paradisi (Macfad.) cv. "Marsh" plants were sampled in the South African grapefruit production areas of Malelane and Pongola. CTV populations from these samples were analysed through the amplification of the p33 gene and subsequent direct Sanger sequencing. A subset of twelve of these amplicons was selected for deep Illumina MiSeq sequencing. The resulting data showed high intra- and inter- orchard diversity of CTV, with populations showing similar genotype compositions to those found in recent studies on the "Star Ruby" cultivar. Populations were
\end{abstract}


composed of a clearly dominant component, in most cases RB or Kpg3/SP/T3-like sequences, with at least two minor sequence types. AT-1-like and VT-like sequences were found to be dominant in only four and one of the analysed populations respectively. HA16-5, Taiwan-Pum/M/T5, T30 and B165 were present as intermittent minor components (less than $10 \%$ of mapped reads) across the populations.

\section{Keywords}

Citrus tristeza virus CTV Grapefruit

Citrus tristeza virus (CTV), a member of the family Closteroviridae (Karasev et al. 1995), is often introduced through infected budwood and spread locally through a number of aphid species (Moreno et al. 2008). It has a diverse phylogeny with six clades considered as discreet strains (Harper 2013) and various disease syndromes may be elicited including asymptomatic infections, decline, stem-pitting, stunting, seedling yellows and quick decline (Bar-Joseph et al. 1989). Citrus paradisi (Macfad.) (grapefruit) cultivars are particularly susceptible (van Vuuren and Manicom 2005), with severe stem-pitting a common symptom in Southern Africa (van Vuuren et al. 2000). Due to the endemism of severe stem-pitting strains in Southern Africa (van Vuuren et al. 2000), cross-protection has become a viable method of reducing the negative effects of CTV (Moreno et al. 2008). The CTV grapefruit mild-strain (GFMS) 12 population was initially employed in South Africa as the crossprotecting selection for grapefruit cultivars but replaced from 1998 by the GFMS 35 population (Luttig et al. 2002). Such candidate cross-protecting sources have usually been evaluated empirically, through biological indexing trials (Moreno et al. 2008). However, since superinfection-exclusion has been proposed as the underlying mechanism of cross protection, and is known to be strain-specific, identifying the strain composition of cross- 
protecting sources, as well as populations present in the field will allow for the improvement of cross-protection as a method for CTV control (Folimonova et al. 2012).

The diversity of CTV populations associated with the "Star Ruby" cultivar has been extensively studied in Southern Africa (Scott et al. 2012; Read and Pietersen 2015; Read and Pietersen 2016) but little is known regarding other cultivars. In the current study, the approach reported by Read and Pietersen, (2016) is used to evaluate the CTV strain composition of thirty-six "Marsh" trees from two sites each of the Malelane and Pongola grapefruit production areas, in South Africa.

Leaf midribs were utilised, and total RNA was extracted, reverse transcriptase PCR directed at the p33 gene, amplicon clean-up, direct Sanger sequencing and Illumina sequencing on a subset of 12 samples, data processing and analyses were all done as described by Read and Pietersen (2016).

Results of direct Sanger sequences of 35 samples are listed in Table 1, along with the sample collection site and the year of planting. The CTV genotype identity was derived following multiple alignment along with known CTV genotype references (Read and Pietersen, 2016). The majority of sequences associated with CTV populations from Malelane, Site B, grouped within the $\mathrm{Kpg} 3 / \mathrm{SP} / \mathrm{T} 3$ group with only a single sequence associated with RB. Sequences derived from Malelane, site A appeared to have more heterogeneous populations with four sequences grouping within the Kpg3/SP/T3 group, three grouping with within the AT-1 group and a two sequences with RB. The majority of the direct sequences associated with the CTV populations from the two collection sites in Pongola grouped within the RB group, with only single sequence associated with each of the following genotypes: Kpg3/SP/T3, AT-1 and VT.

A total of 11160243 illumina sequence reads mapped to the CTV reference sequences after the CLC Genomics reference mapping. Data relating to number of reads mapping to 
CTV references for each sample, as well as percentages of reads mapping to references within the nine clades defined by Read and Pietersen (2016), are listed in Table 2. All Illumina MiSeq datasets were associated with a corresponding direct Sanger sequence. The dominant CTV genotype within each Illumina MiSeq dataset corresponded with the consensus genotype sequence of the direct Sanger sequence in all cases.

The most prevalent genotypes among the Illumina MiSeq datasets was RB and Kpg3/SP/T3, both being present in ten of twelve analysed populations. RB was present at higher levels than Kpg3/SP/T3, with maximum percentages of $99 \%$ and $86.4 \%$ respectively. HA16-5-like sequences were present in nine of the twelve analysed populations, however as a minor component with a maximum percentage of total mapped reads of $10 \%$. VT and AT-1 were minor components in the majority of the populations, except for one population from Pongola, in which VT was dominant (86.2\% of mapped reads) and two populations dominant for AT-1, one from Malelane and one from Pongola, at $56.6 \%$ and $81.2 \%$ respectively. Taiwan-Pum/M/T5, T30 and B165 were all represented as minor sequence types (rarely exceeding $1 \%$ of total mapped reads) in less than half of the populations. Reads mapping to T36 and A18 references were absent from the datasets. 
Table 1: Taxonomic identity of the direct Sanger sequencing data, corresponding to each grapefruit sample collected. Samples from.Malelane (site A and B) and Pongola (Site C and D) production areas.

\begin{tabular}{|c|c|c|c|c|c|}
\hline Rootstock & $\begin{array}{c}\text { Sample } \\
\text { collection site }\end{array}$ & Sample number & $\begin{array}{c}\text { Date } \\
\text { sampled }\end{array}$ & $\begin{array}{l}\text { Year of } \\
\text { planting }\end{array}$ & $\begin{array}{c}\text { Genotype } \\
\text { (dendrogram) }\end{array}$ \\
\hline Troyer citrange & $\mathrm{B}$ & $15-4081$ & $05-2015$ & 1989 & Kpg3/SP/T3 \\
\hline Troyer citrange & $\mathrm{B}$ & $15-4082$ & $05-2015$ & 1989 & $\mathrm{RB}$ \\
\hline Troyer citrange & $\mathrm{B}$ & $15-4083$ & $05-2015$ & 1989 & Kpg3/SP/T3 \\
\hline Troyer citrange & $\mathrm{B}$ & $15-4084$ & $05-2015$ & 1989 & Kpg3/SP/T3 \\
\hline Troyer citrange & $\mathrm{B}$ & $15-4085$ & $05-2015$ & 1989 & Kpg3/SP/T3 \\
\hline Troyer citrange & $\mathrm{B}$ & $15-4086$ & $05-2015$ & 1989 & Kpg3/SP/T3 \\
\hline Troyer citrange & $\mathrm{B}$ & $15-4088$ & $05-2015$ & 1989 & Kpg3/SP/T3 \\
\hline Troyer citrange & $\mathrm{B}$ & $15-4090$ & $05-2015$ & 1989 & Kpg3/SP/T3 \\
\hline Troyer citrange & $\mathrm{B}$ & $15-4091$ & $05-2015$ & 1989 & Kpg3/SP/T3 \\
\hline Troyer citrange & $\mathrm{B}$ & $15-4092$ & $05-2015$ & 1989 & Kpg3/SP/T3 \\
\hline Swingle citrumelo & $\mathrm{A}$ & $15-4093$ & $05-2015$ & 1995 & AT-1 \\
\hline Swingle citrumelo & $\mathrm{A}$ & $15-4094$ & $05-2015$ & 1995 & Kpg3/SP/T3 \\
\hline Swingle citrumelo & $\mathrm{A}$ & $15-4096$ & $05-2015$ & 1995 & AT-1 \\
\hline Swingle citrumelo & A & $15-4097$ & $05-2015$ & 1995 & RB \\
\hline Swingle citrumelo & $\mathrm{A}$ & $15-4098$ & $05-2015$ & 1995 & RB \\
\hline Swingle citrumelo & $\mathrm{A}$ & $15-4099$ & $05-2015$ & 1995 & Kpg3/SP/T3 \\
\hline Swingle citrumelo & $\mathrm{A}$ & $15-4100$ & $05-2015$ & 1995 & Kpg3/SP/T3 \\
\hline Swingle citrumelo & $\mathrm{A}$ & $15-4101$ & $05-2015$ & 1995 & AT-1 \\
\hline Swingle citrumelo & $\mathrm{A}$ & $15-4102$ & $05-2015$ & 1995 & Kpg3/SP/T3 \\
\hline Swingle citrumelo & $\mathrm{C}$ & $15-4117$ & $05-2015$ & 1993 & RB \\
\hline Swingle citrumelo & $\mathrm{C}$ & $15-4120$ & $05-2015$ & 1993 & VT \\
\hline Swingle citrumelo & $\mathrm{C}$ & $15-4124$ & $05-2015$ & 1993 & RB \\
\hline Swingle citrumelo & $\mathrm{C}$ & $15-4125$ & $05-2015$ & 1993 & RB \\
\hline Swingle citrumelo & $\mathrm{C}$ & $15-4127$ & $05-2015$ & 1993 & AT-1 \\
\hline Swingle citrumelo & $\mathrm{C}$ & $15-4128$ & $05-2015$ & 1993 & RB \\
\hline Swingle citrumelo & $\mathrm{D}$ & $15-4106$ & $05-2015$ & 1998 & RB \\
\hline Swingle citrumelo & $\mathrm{D}$ & $15-4107$ & $05-2015$ & 1998 & RB \\
\hline Swingle citrumelo & $\mathrm{D}$ & $15-4108$ & $05-2015$ & 1998 & RB \\
\hline Swingle citrumelo & $\mathrm{D}$ & $15-4109$ & $05-2015$ & 1998 & RB \\
\hline Swingle citrumelo & $\mathrm{D}$ & $15-4110$ & $05-2015$ & 1998 & RB \\
\hline Swingle citrumelo & $\mathrm{D}$ & $15-4112$ & $05-2015$ & 1998 & RB \\
\hline Swingle citrumelo & $\mathrm{D}$ & $15-4113$ & $05-2015$ & 1998 & $\mathrm{RB}$ \\
\hline Swingle citrumelo & $\mathrm{D}$ & $15-4114$ & $05-2015$ & 1998 & Kpg3/SP/T3 \\
\hline Swingle citrumelo & $\mathrm{D}$ & $15-4115$ & $05-2015$ & 1998 & RB \\
\hline Swingle citrumelo & $\mathrm{D}$ & $15-4116$ & $05-2015$ & 1998 & RB \\
\hline
\end{tabular}

Table 2: Results of Illumina MiSeq read mapping to various CTV strains for representative samples from "Marsh" grapefruit trees collected in the Malelane and Pongola production areas in South Africa. The $\dagger$ denotes the sequence type assigned to direct Sanger sequences.

\begin{tabular}{|c|c|c|c|c|c|c|c|c|c|c|c|c|}
\hline $\begin{array}{l}\text { Sample } \\
\text { number }\end{array}$ & $\begin{array}{c}\text { Genotype } \\
\text { (dendrogram) }\end{array}$ & $\begin{array}{l}\text { Total } \\
\text { number of } \\
\text { reads } \\
\text { mapping } \\
\text { to refs }\end{array}$ & $\begin{array}{l}\mathrm{RB} \\
(\%)\end{array}$ & $\begin{array}{c}\mathrm{Kpg} 3 / \mathrm{SP} / \\
\mathrm{T} 3(\%)\end{array}$ & $\begin{array}{c}\mathrm{HA} \\
16-5 \\
(\%)\end{array}$ & $\begin{array}{l}\text { VT } \\
(\%)\end{array}$ & $\begin{array}{l}\text { AT-1 } \\
(\%)\end{array}$ & $\begin{array}{l}\text { T36 } \\
(\%)\end{array}$ & $\begin{array}{c}\text { Taiwan- } \\
\text { Pum/ } \\
\text { M/T5 } \\
(\%)\end{array}$ & $\begin{array}{l}\text { T30 } \\
(\%)\end{array}$ & $\begin{array}{c}\mathrm{B} 165 \\
(\%)\end{array}$ & $\begin{array}{l}\text { A18 } \\
(\%)\end{array}$ \\
\hline $15-4082$ & $\mathrm{RB}$ & 505634 & $74.2 \div$ & 24.4 & 0.9 & - & - & - & 0.2 & 0.3 & - & - \\
\hline $15-4083$ & Kpg3/SP/T3 & 365820 & 5.4 & $86.4 \div$ & 10 & - & - & - & - & - & - & - \\
\hline $15-4090$ & $\mathrm{Kpg} 3 / \mathrm{SP} / \mathrm{T} 3$ & 162646 & 15.2 & $82.6 \div$ & 2.1 & - & 0.1 & - & - & - & - & - \\
\hline $15-4093$ & AT-1 & 780330 & 4.7 & 22.6 & 0.7 & 8.4 & $56.6 \div$ & - & - & - & 7.1 & - \\
\hline $15-4097$ & RB & 4863132 & $88.9 \dagger$ & 6.7 & 0.3 & 0.8 & 2.7 & - & 0.2 & - & 0.4 & - \\
\hline $15-4100$ & Kpg3/SP/T3 & 722319 & 21.5 & $70.6 \div$ & 7.1 & 0.1 & 0.6 & - & 0.1 & - & - & - \\
\hline $15-4107$ & $\mathrm{RB}$ & 722914 & $93.5 \dagger$ & 3.1 & 0.1 & 0.7 & 1 & - & 1.6 & - & - & - \\
\hline $15-4113$ & $\mathrm{RB}$ & 123250 & $99+$ & - & - & - & 0.1 & - & - & 0.9 & - & - \\
\hline $15-4114$ & Kpg3/SP/T3 & 245154 & 9 & $88 \dagger$ & 3 & - & - & - & - & - & - & - \\
\hline $15-4120$ & VT & 352214 & - & 0.4 & - & $86.2 \div$ & 12.5 & - & - & - & 0.9 & - \\
\hline $15-4127$ & AT-1 & 868163 & - & - & - & 10.2 & $81.2 \div$ & - & - & - & 8.7 & - \\
\hline $15-4128$ & $\mathrm{RB}$ & 1448667 & $84.1 \div$ & 13.5 & 0.6 & 0.5 & 1.1 & - & - & - & 0.2 & - \\
\hline
\end{tabular}


The current study represents a significant extension of the study of Read and Pietersen (2016) now in South Africa's second most important grapefruit cultivar, "Marsh", and contributes to the current knowledge of CTV diversity within grapefruit cultivars in this country. Populations always showed a dominant component (genotype specific reads being greater than $50 \%$ of the total CTV mapped reads) with between two to six minor components. In most cases, populations were dominant for $\mathrm{RB}$ or $\mathrm{Kpg} 3 / \mathrm{SP} / \mathrm{T} 3$-like sequences. This supports the previous results of Read and Pietersen (2016) who showed that the distribution of strains within "Star Ruby", as well as a number of other grapefruit cultivars, was often highly heterogeneous, both in South Africa and Argentina (Read et al, 2017). Harper et al. (2015) showed that CTV populations tended to reach equilibrium at the same point within clones of plants, regardless of the viral titre in the original inoculum. The observed heterogeneity among CTV populations on grapefruit could however represent a lack of equilibrium of strains within populations (Harper et al. 2015), but requires further study.

RB components were observed in all CTV populations isolated from "Star Ruby" grapefruit trees in South Africa (Read and Pietersen 2016). This genotype was also most prevalently detected among populations analysed in this study, being undetected in only two populations. Reads mapping to RB-associated reference sequences were also found in the highest percentages, relative to other components, among the most recently planted trees (1998 in this study). This was a trend observed in the previous studies as well. Read and Pietersen (2016) suggest that the dominance of RB components among CTV populations isolated from the most recently planted "Star Ruby" trees within their study, could be the result of pre-immunisation with GFMS12 and that cross-protection breakdown could be occurring due to gradual increase in Kpg3/SP/T3-like components, possibly introduced by vector transmission. Since many of the same trends were observed for populations associated 
with "Marsh" grapefruit trees, breakdown of cross-protection for this cultivar could be occurring through similar mechanisms.

The improvement of grapefruit cross-protection lies in the determination of which strains have an affinity for particular cultivars, growing under certain climatic conditions, and targeting components of those populations known to cause a breakdown of cross-protection. This study has shown the dynamics of CTV populations associated with pre-immunised "Marsh" grapefruit in South Africa. This has provided indications to which components are involved in cross-protection breakdown and which strains should be focussed on for improving mild-strain cross-protecting sources.

\section{Acknowledgement}

We would like to acknowledge funding from the National Research Foundation (South Africa) and Ministerio de Ciencia, Tecnologia e Innovación Productiva (Argentina) via the South AfricaArgentina Bilateral agreement programme.

\section{References}

Bar-Joseph M., Marcus R. and Lee R.F. (1989). The continuous challenge of Citrus Tristeza Virus Control. Annual Reviews in Phytopathology, 27, 291-316

Folimonova S.Y. (2012). Superinfection Exclusion Is an Active Virus-Controlled Function That Requires a Specific Viral Protein. Journal of Virology, 86, 5554-5561

Harper S.J. (2013). Citrus tristeza virus: evolution of complex and varied genotypic groups. Frontiers in Microbiology, 4, 93 
Harper S. J., Cowell S. J. \& Dawson W. O. (2015). Finding balance: virus populations reach equilibrium during the infection process. Virology, 485, 205-212.

Karasev A.V., Boyko V.P., Gowda S., Nikolaeva O.V., Hilf M.E., Koonin E.V., et al.. (1995). Complete Sequence of the Citrus Tristeza Virus RNA Genome. Virology, 208, 511-520

Luttig, M., van Vuuren, S. P., \& van der Vyver, J. B. (2002). Differentiation of single aphid cultured sub-isolates of two South African Citrus tristeza virus isolates from grapefruit by single-strand conformation polymorphism. In: proc $15^{\text {th }}$ Conf (pp. 186-196). IOCV, Riverside, California: IOCV.

Moreno P., Ambros S., Albiach-Marti M.R., Guerri J. and Pena L. (2008). 'Citrus tristeza virus: A pathogen that changed the course of the citrus industry'. Molecular Plant Pathology, 9, 251-268

Read, D.A., \& Pietersen, G. (2015). Genotypic diversity of Citrus tristeza virus within red grapefruit, in a field trial site in South Africa. European Journal of Plant Pathology, 142, 531-545.

Read, D.A., \& Pietersen, G. (2016). Diversity of Citrus tristeza virus populations in commercial grapefruit orchards in Southern Africa, determined using Illumina MiSeq technology. European Journal of Plant Pathology, 148, 379 - 391

Read D.A., Palacios, M.F., Kleynhans, J., Figueroa, J., Foguet, L., Stein, B. and Pietersen, G. (2017). Survey of Citrus tristeza virus (CTV) diversity of in pigmented Citrus $x$ paradisi (Macfad.) (Grapefruit) trees in north-western Argentina. European Journal of Plant Pathology, doi: $10.1007 / \mathrm{s} 10658-017-1376-5$

Scott K.A., Hlela Q., Zablocki O., Read D., van Vuuren S. and Pietersen G. (2012). Genotype composition of populations of grapefruit-cross-protecting citrus tristeza virus strain GFMS12 in different host plants and aphid-transmitted sub-isolates. Archives of Virology, 158, 27 - 37 
van Vuuren S.P, van der Vyver J.B. and Luttig M. (2000). Diversity Among Sub-Isolates of CrossProtecting Citrus Tristeza Virus Isolates in South Africa. In: Proc. 14th Conf. IOCV, 103-110 IOCV, Riverside, California

van Vuuren S.P. (2002). Effects of Citrus tristeza virus isolates on two tolerant commercial scions on different rootstocks in South Africa. In: Proc. $15^{\text {th }}$ Conf. IOCV, $31-38$ IOCV, Riverside, California

van Vuuren S.P. and Manicom B.Q. (2005). The Response of Star Ruby Grapefruit to Different Citrus tristeza virus isolates. In: Proc 16th Conf. IOCV, 112-116 IOCV, Riverside, California 